\title{
Production of Guanosine by Sulfaguanidine Resistant Mutants of Bacillus subtilis
}

\author{
Hiroshi Matsui, Katsuaki Sato, Hitoshi EneI and Yoshio Hrrose \\ Central Research Laboratories of Ajinomoto Co., Inc., \\ Kawasaki, Japan \\ Received October 11, 1977
}

\begin{abstract}
Bacillus subtilis 14119 that produced inosine and guanosine or Bacillus subtilis AG169 that produced xanthosine and guanosine was mutated to resistance against sulfaguanidine. Among the mutants derived, those that showed the increased production of guanosine were observed frequently. Of these mutants, strains T104 and GS-1 produced 11.0 and $10.0 \mathrm{~g}$ of guanosine per liter of the culture broth at weight yields of 13.8 and $12.5 \%$ from consumed sugar, respectively.

In these strains, the specific activity of GMP synthetase was higher than that of the parental strain, and furthermore in T104, that of IMP dehydrogenase also was higher. Thus, it is speculated that the metabolic flow from XMP to GMP, especially in T104 from IMP to XMP too, proceeds smoothly and yields more guanosine.
\end{abstract}

On the microbial production of guanosine so far, there have been many studies. Konishi and Shiro $^{1 /}$ derived 8-azaguanine resistant mutants lacking succino-AMP synthetase and GMP reductase from Bacillus subtilis that produced $4 \mathrm{~g}$ of guanosine per liter. Momose and Shiio $^{2}$ also obtained 8-azaxanthine resistant mutants lacking succino-AMP synthetase and GMP reductase from $B$. subtilis that produced $5 \mathrm{~g}$ of guanosine per liter. Nogami et al. ${ }^{3}$ derived adenosine resistant mutants from Bacillus sp. that produced $5 \mathrm{~g}$ of guanosine per liter and they found that the activity of the GMP synthetase of these mutants was not inhibited by adenosine. Komatsu et al. ${ }^{4}$ obtained mutants of $B$. subtilis that were deficient in nucleoside phosphorylase and produced $10 \mathrm{~g}$ of guanosine per liter.

Recently, it has been shown by the authors ${ }^{53}$ that methionine sulfoxide resistant mutants derived from an inosine producing strain accumulated more guanosine and less inosine than the parent. And it was indicated that the methionine sulfoxide resistance caused mainly the variation of $5^{\prime}$-nucleotidase.

Now, further mutation to sulfaguanidine resistance was brought in practice from an inosine and guanosine producer 14119 or a xanthosine and guanosine producer AG169. A part of the sulfaguanidine resistant mutants showed increased production of guanosine. The present paper describes the derivation of improved guanosine producing mutants from strains 14119 and AG169, and the clarification of some of their properties, especially the correlation of sulfaguanidine resistance with guanosine productivity and the activities of enzymes involved in the conversion of IMP to GMP.

\section{MATERIALS AND METHODS}

Bacterial strains. The sulfaguanidine resistant mutants were derived from an inosine and guanosine producing auxotroph of Bacillus subtilis 14119 and a xanthosine and guanosine producing auxotroph of $B$. subtilis AG169. The genetic characteristics of these parental strains were adenine- and histidine-less, lacking GMP reductase and succino-AMP synthetase, and were resistant to the methionine sulfoxide.

Culture media. Medium-1 contained $10 \mathrm{~g}$ of polypepton, $10 \mathrm{~g}$ of yeast extract, $5 \mathrm{~g}$ of $\mathrm{NaCl}, 5 \mathrm{~g}$ of glucose and distilled water, in a total volume of 1 liter. The $\mathrm{pH}$ was adjusted to 7.0 with $\mathrm{NaOH}$. Medium-2 contained $20 \mathrm{~g}$ of glucose, $5 \mathrm{~g}$ of $\mathrm{NH}_{4} \mathrm{Cl}, 4 \mathrm{~g}$ of $\mathrm{KH}_{2} \mathrm{PO}_{4}$, $0.2 \mathrm{~g}$ of $\mathrm{MgSO}_{4} \cdot 7 \mathrm{H}_{2} \mathrm{O}, 0.01 \mathrm{~g}$ of $\mathrm{FeSO}_{4} \cdot 7 \mathrm{H}_{2} \mathrm{O} .0 .01 \mathrm{~g}$ 
of $\mathrm{MnSO}_{4} \cdot 4 \mathrm{H}_{2} \mathrm{O}, 0.5 \mathrm{~g}$ of sodium citrate, $1 \mathrm{~g}$ of $\mathrm{L}$ glutamic acid, $0.5 \mathrm{~g}$ of L-histidine, $0.1 \mathrm{~g}$ of adenine and distilled water, in a total volume of 1 liter. The $\mathrm{pH}$ was adjusted to 7.0 with $\mathrm{KOH}$. Medium-3 contained $80 \mathrm{~g}$ of glucose, $15 \mathrm{~g}$ of $\mathrm{NH}_{4} \mathrm{NO}_{3}, 0.2 \mathrm{~g}$ of $\mathrm{KH}_{2} \mathrm{PO}_{4}$, $0.4 \mathrm{~g} \mathrm{of} \mathrm{MgSO}_{4} \cdot 7 \mathrm{H}_{2} \mathrm{O}, 0.01 \mathrm{~g}$ of $\mathrm{FeSO}_{4} \cdot 7 \mathrm{H}_{2} \mathrm{O}, 0.01 \mathrm{~g}$ of $\mathrm{MnSO}_{4} \cdot 4 \mathrm{H}_{2} \mathrm{O}, 2 \mathrm{~g}$ of $\mathrm{CaCl}_{2} \cdot 2 \mathrm{H}_{2} \mathrm{O}, 0.3 \mathrm{~g}$ of DLmethionine, $10 \mathrm{~g}$ of L-glutamic acid, $0.3 \mathrm{~g}$ of L-histidine, $40 \mathrm{ml}$ of Ajieki (soybean hydrolysate), $1.2 \mathrm{~g}$ of RNA, $15 \mathrm{~g}$ of $\mathrm{CaCO}_{3}$ and distilled water, in a total volume of 1 liter. The $\mathrm{pH}$ was adjusted to 7.5 with $\mathrm{KOH}$. Calcium carbonate was sterilized separately.

Derivation of mitants. Cells $\left(1 \times 10^{9}\right.$ to $\left.5 \times 10^{9}\right)$ from the logarithmic growth phase in medium-1 were harvested, washed with $50 \mathrm{~mm} \mathrm{KH}_{2} \mathrm{PO}_{4}-\mathrm{K}_{2} \mathrm{HPO}_{4}$ buffer ( $\mathrm{pH} 7.0$ ) and exposed to $500 \mu \mathrm{g}$ of $\mathrm{N}$-methyl$\mathrm{N}^{\prime}$-nitro- $\mathrm{N}$-nitrosoguanidine ( $\mathrm{NG}$ ) per $\mathrm{ml}$ in the same phosphate buffer for $50 \mathrm{~min}$ in an ice bath. The NGtreated cells were washed with the same phosphate buffer, diluted and spread on medium-2 agar plates supplemented with sulfaguanidine. After incubation for 2 to 5 days at $34^{\circ} \mathrm{C}$, colonies that appeared on the plates were picked up.

Fermentation tests. Cells that grew overnight on medium-1 agar plates were inoculated into $20 \mathrm{ml}$ of medium-3 in a $500 \mathrm{ml}$-flask. After cultivation for $72 \mathrm{hr}$ at $34^{\circ} \mathrm{C}$ with shaking, $10 \mu \mathrm{l}$ of the culture broth was spotted on filter paper (Toyo Roshi No. 51). After separation by paper chromatography, using isopropanol-ammonia-water $(7: 2: 1)$ as the solvent, inosine, xanthosine and guanosine were extracted from the paper with $10 \mathrm{ml}$ of $0.1 \mathrm{~N} \mathrm{HCl}$ for $5 \mathrm{hr}$ at room temperature and were estimated spectrophotometrically.

Growth inhibition tests. Bacterial cells grown overnight in $3 \mathrm{ml}$ of medium-2 in a test tube were washed with $50 \mathrm{~mm} \mathrm{KH} \mathrm{KO}_{t}-\mathrm{K}_{2} \mathrm{HPO}_{t}\left(\mathrm{pH} 7.0\right.$ ) and about $10^{8}$ cells were inoculated into $3 \mathrm{ml}$ of medium-2 supplemented with sulfaguanidine. The growth was measured by absorbance at $540 \mathrm{~nm}$ after culturing for 24 hr at $34^{\circ} \mathrm{C}$.

Enzyme preparation. The cells that had grown overnight on medium-1 agar plates were transferred to $20 \mathrm{ml}$ of the inoculum medium, the composition being the same as that of medium-3 except $\mathrm{CaCO}_{3}$ was omitted. After cultivation for 16 to $20 \mathrm{hr}$ at $34^{\circ} \mathrm{C}$, the cells were harvested from the culture broth by centrifugation, washed twice with a $0.85 \% \mathrm{NaCl}$ solution and three times with chilled acetone, and dried in a vacuum. For GMP synthetase preparation, the harvested cells were washed with a $0.85 \% \mathrm{NaCl}$ solution containing $0.1 \mathrm{M}$ ethylenediaminetetraacetic acid. The acetonedried cells were used to assay the activities of IMP dehydrogenase, GMP synthetase and 5'-nucleotidase. For the glutamine synthetase preparation, the harvested cells were washed twice with $50 \mathrm{mM} \mathrm{KH}_{2} \mathrm{PO}_{4}-\mathrm{K}_{2} \mathrm{HPO}_{4}$ buffer (pH 7.0) and treated with $500 \mu \mathrm{g}$ of lysozyme per $\mathrm{ml}$ and $5 \mu \mathrm{g}$ of deoxyribonuclease per $\mathrm{ml}$ in the same phosphate buffer for $30 \mathrm{~min}$ at $37^{\circ} \mathrm{C}$. The lysate was centrifuged at $12,000 \times g$ for $20 \mathrm{~min}$ and the supernatant was used to assay the activity of the glutamine synthetase.

Enzyme activity assay. The activities of IMP dehydrogenase, GMP synthetase, 5'-nucleotidase and glutamine synthetase were assayed by the methods of Konishi and Shiro, ${ }^{1 /}$ Moyed and Magasanik, ${ }^{\text {(1) Heppel }}$ and Hilmoe,7) and Elliott and Gale, ${ }^{87}$ respectively. Specific activities of the enzymes were expressed as nmol per min per milligram of dried cells or protein. The protein content was estimated by the method of Lowry et al. ${ }^{\text {! }}$

\section{RESULTS}

Growth inhibition by sulfaguanidine and recovery of the inhibition by purine bases, amino acids and vitamins

The growth of strain 14119 on medium-2 was inhibited by the addition of 0.1 and $0.5 \mathrm{mg}$ of sulfaguanidine per $\mathrm{ml}$. The growth inhibition could be reversed completely by using $0.1 \mathrm{mg}$ of $p$-aminobenzoic acid per ml, but not reversed through the usage of hypoxanthine, xanthine, guanine, L-glutamic acid, L-glutamine and folic acid. The results are presented in Table I.

Derivation of sulfaguanidine resistant mutants from strains 14119 and $A G 169$, and their guanosine productivity

The NG-treated cells were spread on medium-2 agar plates containing 0.1 to $1.0 \mathrm{mg}$ of sulfaguanidine per $\mathrm{ml}$, and the colonies that appeared were picked up, transferred to test tubes containing $3 \mathrm{ml}$ of medium -3 and cultured for $72 \mathrm{hr}$ at $34^{\circ} \mathrm{C}$. Those that produced more than $10 \mathrm{~g}$ of guanosine per liter were selected (first screening test). The parental strains 14119 and AG169 produced 8.5 and $7.0 \mathrm{~g}$ of guanosine per liter under these conditions, respectively. Mutants improved in guanosine productivity were obtained with high frequency from mutants resistant to the concentration of 0.5 to $1.0 \mathrm{mg}$ of sulfaguanidine per $\mathrm{ml}$ (Table II). These mutants were then purified by 
Table 1. Growth INHIBITION BY SUlfaguanidine AND ReCOVERY OF THE Inhibition by PURINe BASEs, AmINo Acids AND Vitamins

Bacillus subtilis 14119 was used.

\begin{tabular}{|c|c|c|c|c|}
\hline \multirow{3}{*}{$\begin{array}{c}\text { Addition to } \\
\text { medium-2 } \\
(\mathrm{mg} / \mathrm{ml})\end{array}$} & & \multicolumn{3}{|c|}{ Growth response $(\%)$} \\
\hline & & & \multicolumn{2}{|c|}{$\begin{array}{l}\text { Sulfaguanidine } \\
(\mathrm{mg} / \mathrm{ml})\end{array}$} \\
\hline & & & 0.1 & 0.5 \\
\hline None & & 100 & 0 & 0 \\
\hline Hypoxanthine & 0.1 & 86 & 0 & 0 \\
\hline Xanthine & 0.1 & 107 & 0 & 0 \\
\hline Guanine & 0.1 & 72 & 0 & 0 \\
\hline L-Glutamic acid & 10 & 153 & 0 & 0 \\
\hline L-Glutamine & 10 & 178 & 9 & 0 \\
\hline $\begin{array}{l}p \text {-Aminobenzoic } \\
\text { acid }\end{array}$ & 0.1 & 128 & 126 & 112 \\
\hline " & 1.0 & 74 & 69 & 64 \\
\hline Folic acid & 0.1 & 128 & 0 & 0 \\
\hline
\end{tabular}

Table II. Appearance of Sulfaguanidine Resistant MUtants and Therr INCREASED Guanosine Producers

The fermentation tests were carried out by culturing for $72 \mathrm{hr}$ at $34^{\circ} \mathrm{C}$ using $3 \mathrm{ml}$ of medium-3 in a test tube.

\begin{tabular}{lcccc} 
Strain & $\begin{array}{c}\text { Sulfa- } \\
\text { guanidine } \\
(\mathrm{mg} / \mathrm{ml})\end{array}$ & $\begin{array}{c}\text { Number } \\
\text { of tested } \\
\text { colonies }\end{array}$ & $\begin{array}{c}\text { Number } \\
\text { of selected } \\
\text { colonies } \\
\left(\mathrm{GR}^{a)}:>\right. \\
10 \mathrm{~g} / \mathrm{liter})\end{array}$ & $\begin{array}{c}\text { Fre- } \\
\text { quency } \\
(\%)\end{array}$ \\
\hline 14119 & 0.1 & 83 & 1 & 1.2 \\
14119 & 0.5 & 38 & 14 & 37 \\
14119 & 1.0 & 5 & 2 & 40 \\
AG169 & 0.5 & 50 & 5 & 10 \\
\hline
\end{tabular}

a) GR, guanosine.

using the single colony isolation technique, and their guanosine productivity was determined in medium-3 in that the concentration of RNA was varied to $1.0,1.2$ and $1.4 \mathrm{~g} /$ /iter (second screening test). The parent 14119 accumulated $9.6 \mathrm{~g}$ of guanosine and $4.8 \mathrm{~g}$ of inosine per liter at its optimal RNA concentration. A mutant T104 from 14119 accumulated $11.0 \mathrm{~g}$ of guanosine, $1.0 \mathrm{~g}$ of xanthosine and $5.0 \mathrm{~g}$ of inosine per liter. The other parent AG169 accumulated $8.0 \mathrm{~g}$ of guanosine and $6.0 \mathrm{~g}$ of xanthosine per liter. A mutant GS-1 from AG169 accumulated $10.0 \mathrm{~g}$ of guanosine and $3.8 \mathrm{~g}$ of xanthosine per liter (Table III).

Furthermore, growth inhibition of these strains by sulfaguanidine was investigated (Fig. 1). Mutants T104 and GS-1 were slightly more resistant to sulfaguanidine than the parents 14119 and AG169, respectively, but not completely resistant.

Properties of the enzymes relating to the conversion of IMP to GMP in sulfaguanidine resistant mutants

The guanosine productivity of the sulfaguanidine resistant mutants, T104 and GS-1, increased as shown in Table III. From the facts, it is imagined that the enzymes relating to the conversion of IMP to GMP are varied in these mutants. Therefore, the four enzymes of IMP dehydrogenase, GMP synthetase, 5'nucleotidase and glutamine synthetase were assayed.

IMP dehydrogenase converts IMP to XMP. The specific activity of this enzyme in the sulfaguanidine resistant mutant T104 increased when compared with that of the parent 14119. But no difference could be found between mutant GS-1 and the parent AG169. Inhibition of the enzyme activity by $0.55 \mathrm{mM}$ GMP was not observed in any of the four strains. The results are presented in Table IV.

Table III. Purine Nucleoside Productuvtty of Sulfaguanidine Resistant Mutants and the Parents

\begin{tabular}{lcccc}
\hline Strain (parent) & \multicolumn{2}{c}{ Productivity $(\mathrm{g} /$ liter) } & \\
\cline { 2 - 5 } & Inosine & Xanthosine & Guanosine & $\begin{array}{c}\text { Total purine } \\
\text { nucleoside }\end{array}$ \\
\hline T104 (14119) & 5.0 & 1.0 & 11.0 & 17.0 \\
14119 & 4.8 & 0 & 9.6 & 14.4 \\
GS-1 (AG169) & 0 & 3.8 & 10.0 & 13.8 \\
AG169 & 0 & 6.0 & 8.0 & 14.0 \\
\hline
\end{tabular}



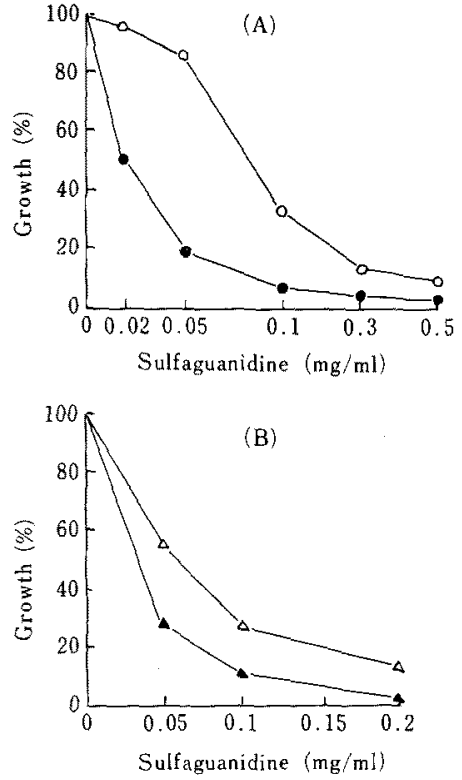

FIG. 1. Growth Inhibition by Sulfaguanidine in Sulfaguanidine Resistant Mutants and the Parents.

(A) $0-0$, T104 (mutant); - 14119 (the parent).

(B) $\triangle-\triangle$, GS-1 (mutant); - A A 169 (the parent).

Table IV. IMP Dehydrogenase ACtivity AND

Its Inhibition by GMP in Sulfaguanidine Resistant Mutants

\begin{tabular}{lcc}
\hline Strain (parent) & \multicolumn{2}{c}{$\begin{array}{c}\text { Specific activity of IMP } \\
\text { dehydrogenase } \\
\text { (nmol/min/mg of dried cells) }\end{array}$} \\
\cline { 2 - 3 } & No addition & $0.55 \mathrm{mM} \mathrm{GMP}$ \\
\hline T104 (14119) & 20.5 & 20.6 \\
14119 & 12.5 & 12.3 \\
GS-1 (AG169) & 14.7 & 14.5 \\
AG169 & 13.9 & 13.9 \\
\hline
\end{tabular}

Table V. GMP Synthetase Activity and Its INHIBITION BY GMP IN SULFAGUANIDINE Resistant Mutants

\begin{tabular}{llll}
\hline \multirow{2}{*}{ Strain (parent) } & \multicolumn{3}{c}{$\begin{array}{c}\text { Specific activity of GMP } \\
\text { synthetase }\end{array}$} \\
\cline { 2 - 4 } & $\begin{array}{c}\text { No } \\
\text { (nddition }\end{array}$ & $\begin{array}{c}0.6 \mathrm{mM} \\
\text { GMP }\end{array}$ & $\begin{array}{l}4 \mathrm{mM} \\
\text { GMP }\end{array}$ \\
\hline T104 (14119) & 1.96 & 1.88 & 1.45 \\
14119 & 0.568 & 0.572 & 0.426 \\
GS-1 (AG169) & 1.19 & 1.10 & 1.02 \\
AG169 & 0.563 & 0.560 & 0.450 \\
\hline
\end{tabular}

GMP synthetase forms GMP from XMP, glutamine and ATP. The specific activity of this enzyme in the sulfaguanidine resistant mutants, T104 and GS-1, increased about three times and two times of that of the parents, 14119 and $A G 169$, respectively. Inhibition of the enzyme activity by GMP was not observed at $0.6 \mathrm{mM}$ GMP, but at the high level of $4 \mathrm{mM}$ GMP in all of the four strains. The results are presented in Table $V$.

5 -Nucleotidase forms nucleoside and inorganic phosphate, degrading 5'-nucleotide, 5'IMP, 5'-XMP and 5'-GMP, here, were used as substrates of $5^{\prime}$-nucleotidase. Although the specific activities of AG169 and GS-1 were remarkably lower than those of 14119 and $\mathrm{T} 104$, variations of the specific activity between mutants and the parents could not be recognized at all (Table VI).

Table VI. 5'-NuCleotidase ACtivity in Sulfaguanidine Resistant Mutants

\begin{tabular}{lccc}
\hline Strain (parent) & \multicolumn{2}{c}{$\begin{array}{c}\text { Specific activity of } 5^{\prime} \text {-nucleo- } \\
\text { tidase } \\
\text { (nmol/min/mg of dried cells) }\end{array}$} \\
\cline { 2 - 4 } & \multicolumn{3}{c}{ Substrates } \\
\hline T104 (14119) & 2.74 & 0.343 & 2.14 \\
14119 & 2.83 & 0.343 & 1.89 \\
GS-1 (AG169) & 0.925 & 0.135 & 1.23 \\
AG169 & 0.815 & 0.129 & 1.11 \\
\hline
\end{tabular}

Glutamine synthetase forms glutamine from glutamic acid, ammonia and ATP. And the glutamine is used as the substrate of GMP synthetase in part. The specific activity of this enzyme in the sulfaguanidine resistant mutant T104 decreased slightly in comparison with the parent 14119 , but no difference could be found between mutant GS-1 and the parent AG169 (Table VII).

Table VII. Glutamine Synthetase Activity In Sulfaguanidine Resistant MUTANTS

\begin{tabular}{lc} 
Strain (parent) & $\begin{array}{c}\text { Specific activity of } \\
\text { glutamine synthetase } \\
\text { (nmol/min/mg of protein) }\end{array}$ \\
\hline T104 (14119) & 61.7 \\
14119 & 80.0 \\
GS-1 (AG169) & 78.3 \\
AG169 & 81.5 \\
\hline
\end{tabular}




\section{DISCUSSION}

The mode of action of sulfonamides containing sulfaguanidine has, up to the present, been regarded as the competition with $p$-aminobenzoic acid, namely the inhibition of one carbon transfer reaction and furthermore the inhibition of IMP biosynthetic pathway. ${ }^{10}$ ) Therefore, mutation to sulfonamides resistance may be expected to alter genetically the metabolic flow to IMP biosynthesis. Accordingly, these mutants may accumulate larger amounts of inosine and guanosine than the parent due to the alteration of IMP biosynthetic enzymes.

The growth of $B$. subtilis 14119 and AG169 that were GMP reductase negative adenine auxotrophs was inhibited by a low concentration of sulfaguanidine. Thus, from these two strains, sulfaguanidine resistant mutants were derived. Surprisingly, the mutants, instead of producing inosine, showed increased production of guanosine and were found with high frequency among the mutants resistant against 500 or $1000 \mu \mathrm{g}$ of sulfaguanidine per $\mathrm{ml}$ (Table II). The best mutant T104 obtained from 14119 accumulated $11.0 \mathrm{~g}$ of guanosine per liter, which was $15 \%$ higher than that of the parent. The best mutant GS-1 obtained from AG169 accumulated $10.0 \mathrm{~g}$ of guanosine per liter, which was $25 \%$ higher than that of the parent (Table III). These facts depend on alteration of the enzymes which convert IMP to GMP in mutants T104 and GS-1. Therefore, the four enzymes, IMP dehydrogenase, GMP synthetase, $5^{\prime}$-nucleotidase and glutamine synthetase, of these mutants which are closely related to converting IMP to GMP were investigated. In the case of GS-1, the variations of IMP dehydrogenase, $5^{\prime}$-nucleotidase and glutamine synthetase were not observed at all in comparison with the parent AG169, but the level of GMP synthetase was higher than that of the parent. From this fact, as XMP is converted rapidly to GMP, it seems that a larger amount of guanosine is accumulated and xanthosine production decreases concomitantly.

In the case of $\mathrm{T} 104$, the following multiple variations were caused that the specific activities of IMP dehydrogenase and GMP synthetase were higher than those of the parent 14119 , and the specific activity of glutamine synthetase was slightly lower. 5'-Nucleotidase did not vary. As the results, IMP is readily converted to GMP by way of XMP, and increased production of guanosine was found. Furthermore, T104 did not decrease the inosine formation, but increased the production of total purine nucleosides (Table III). Namely, in T104, the sulfaguanidine resistance seems to strengthen the metabolic flow to IMP biosynthesis, too. However, though overcome by $p$-aminobenzoic acid, growth inhibitions of strains 14119 and AG169 by sulfaguanidine were not reversed by adding hypoxanthine, xanthine, guanine and folic acid (Table I, data not shown in AG169). At present, we are unable to clarify why the sulfaguanidine resistance causes the increases of specific activity in GMP synthetase and IMP dehydrogenase, and the elevation of IMP biosynthetic pathway. Perhaps the mode of action of sulfaguanidine may be multiple.

Acknowledgements. We wish to give thanks to Dr. M. Takahashi, Dr. H. Okada, Dr. T. Shiro and Dr. K. Takinami of the Central Research Laboratories, Ajinomoto Co., Inc., for their encouragement during the course of this work.

\section{REFERENCES}

1) S. Konishi and T. Shiro, Agric. Biol. Chem., 32, 396 (1968).

2) H. Momose and I. Shiio, J. Gen. Appl. Microbiol., 15, 399 (1969).

3) I. Nogami, M. Kida, I. Iijima and M. Yoneda, Agric. Biol. Chem., 32, 144 (1968)

4) K. Komatsu, A. Saijo, R. Kodaira and T. Osawa, Hakko To Taisha, 22, 54 (1970).

5) H. Matsui, K. Sato, H. Enei and Y. Hirose, Appl. Environ. Microbiol., 34, 337 (1977).

6) H. S. Moyed and B. Magasanik, J. Biol. Chem., 226, 351 (1957).

7) L. A. Heppel and R. J. Hilmoe, ibid., 188, 665 (1951).

8) W. H. Elliott and E. F. Gale, Natue, 161, 129 (1948).

9) O. H. Lowry, N. J. Rosebrough, A. L. Farr and R. J. Randall, J. Biol. Chem., 193, 265 (1951).

10) G. M. Brown, ibid., 237, 536 (1962). 